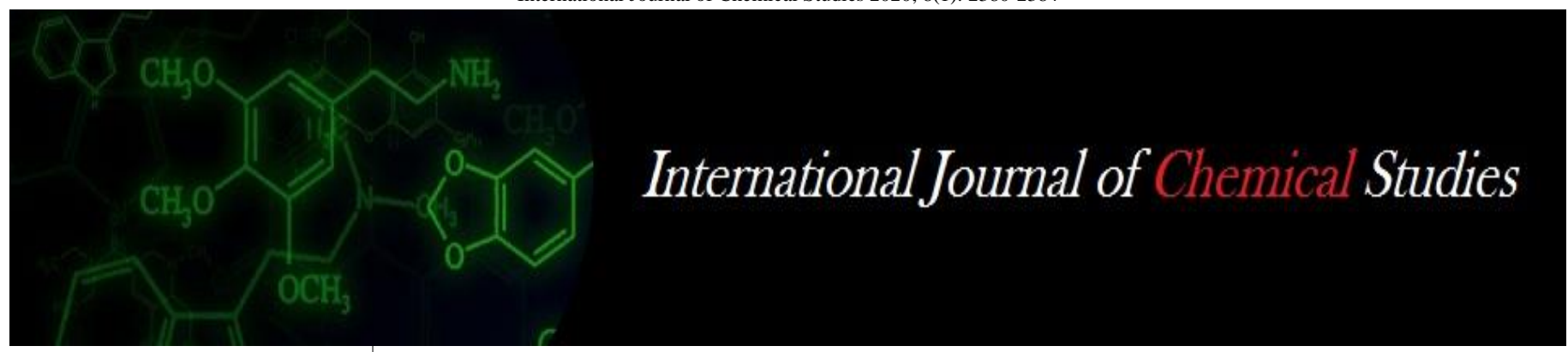

P-ISSN: 2349-8528

E-ISSN: 2321-4902

IJCS 2020; 8(1): 2380-2384

(C) 2020 IJCS

Received: 16-11-2019

Accepted: 18-12-2019

KM Sheetal Banga

ICAR-Central Institute of

Agricultural Engineering,

Bhopal, Madhya Pradesh, India

Sunil Kumar

CCSHAU, Hisar, Haryana, India

Nachiket Kotwaliwale

ICAR-Central Institute of

Agricultural Engineering,

Bhopal, Madhya Pradesh, India

Debabandya Mohapatra

ICAR-Central Institute of

Agricultural Engineering,

Bhopal, Madhya Pradesh, India

Corresponding Author:

KM Sheetal Banga

ICAR-Central Institute of

Agricultural Engineering,

Bhopal, Madhya Pradesh, India

\section{Major insects of stored food grains}

\author{
KM Sheetal Banga, Sunil Kumar, Nachiket Kotwaliwale and Debabandya \\ Mohapatra
}

DOI: https://doi.org/10.22271/chemi.2020.v8.i1aj.8624

\begin{abstract}
Insects are the major threat for causing the post-harvest losses in stored food grains. It causes the qualitative as well as quantitative losses in cereals, food legumes and oilseeds during the storage. To reduce the losses caused by insects, it is necessary to know the type of insects occurred in specific food grains. Damage caused by insect infestation in stored food grains affects the processing quality as well as reduced the nutritional quality. This article represents an overview of major insects of stored food grains.
\end{abstract}

Keywords: Insects, food legumes, oilseeds, cereals, storage

\section{Introduction}

About $10 \%$ of post-harvest losses are incurred in total food grains due to insects, rodents, micro-organisms, improper storage etc. In India, about 14 million tonnes (MT) of food grains of worth Rs. 7000 crores storage losses have been lost annually. Among these losses, insects alone are responsible for losses of about Rs. 1300 crores (Anonymous, 2015) ${ }^{[4]}$. Post-harvest losses due to storage and insect accounts for 2-4.2\% (Kuamr and Kalta, 2017). Insects not only cause the losses in economic terms by consumption alone but also due to spreading contamination also. About 600 species of insects are occurred in stored grains and among these, about 100 species caused economic losses in stored grains (Neethirajan et al., 2007).

Several types of insect occurs which causes the infestation in stored food grains- primary, secondary and tertiary insect. Some insects are behave as free-living insects, visualized to the eye during the first examination and hidden insects are those insects which exist in individual grains due to their immature stage or due to their development in the grains. Insect's response to various natural and simulated features, classified into behavioral and metabolic responses. Movement of insects in stored grains in storage structures lies on environmental conditions. In the summer season, insect infestation occurs on the grain surface and disseminated in clumps throughout the mass, while in the winter season, insects flock in the lower and center portions of the storage structure. Attraction towards supportive conditions and evasion from fumigants, or treated surfaces comes into behavioral aspects whereas metabolic response includes the responses, which are used to promote or demote the development of insects (Bell, 2014) ${ }^{[11]}$.

Primary insects are those which have the ability to bite or pierce intact and stable grains e.g. grain weevils (Curculionidae) major insect of stored cereal grains. Whole sound grains stable when its temperature and moisture content are below the levels required for germination. Primary insects attack the grain first. They have the ability to break down the hard seed coat of the whole grain and they laid the eggs inside the kernel, and the growing larvae cause the infestation inside of the kernel. Primary insects often develop and reproduce very quickly in the optimal conditions, which allows for large populations. They are usually more destructive than secondary pests, especially in short-term storage of food grains (Banga et al., 2018) ${ }^{[7]}$.

Secondary insects follow the primary insects. They feed the grains that are broken by the primary insects, processed into products viz. flour, dal etc. or damaged by poor threshing, drying and handling e.g. red flour beetle (Tribolium castaneum) common secondary insect of wheat. Secondary insects eat the grain from the outside first. The presence of secondary insect often indicates that the grain is not in superlative condition and that measures should be implemented to protect the grain from a further decline in quality. Tertiary insects feed on broken grains, grain dust, and powder left by the primary and secondary insects. 
Confused flour beetle is a tertiary insect of whole grains. Also, it is a secondary insect of milled grains such as flour.

\section{Problems Due to Infestation}

Infestation caused by insects imposed several losses viz. weight loss, viable value loss, and Commercial value loss, nutritional loss health hazards, storability loss etc. (Neethitrajan et al., 2007; Banga et al., 2018) ${ }^{[7]}$

\section{Major Insects of Stored Food Grains}

High post-harvest losses during storage are mainly occurred by two major groups of insects: Coleoptera (beetles) and Lepidoptera (moths and butterflies). Lepidoptera damage the grain during the larvae stage while in the case of Coleoptera, both larvae and adults damage the grain (Sallam, 2008) ${ }^{[44]}$. Coleoptera causes the more destruction in stored food grains as compared to lepidoptera (Upadhyay and Ahmad, 2011) ${ }^{[54]}$. Prevention of insect infestation in stored food grains requires low moisture content and low temperature. The safe moisture content for long term storage of cereals should be below $12 \%$, pulses are $10-12 \%$ and $7-9 \%$ for oil seeds (Chakravarty, 2014). The safe grain storage temperature for grains should be kept below $5{ }^{\circ} \mathrm{C}$ for mites, $15^{\circ} \mathrm{C}$ for insects and $10^{\circ} \mathrm{C}$ for molds (Chakravarty, 2014) ${ }^{[14]}$. Evolution of insects molds and mites seized below $10 \%$ and $13 \%$ moisture content in stored food grains (Banga et al., 2018) ${ }^{[7]}$. Major insects of stored foodgrains with their classification, life span etc. is entitled in table 1. Bulk storage of food grains also affects the infestation rate, $50 \mathrm{MT}$ or larger stored food grain in silos/bins cools slowly and hence may cause more spoilage as compared to the smaller structures with a capacity of 27 tonnes or lesser (Kumar \& Rai, 2014) ${ }^{[25]}$.

Table 1: Summary of Major Stored Food Grain Insects

\begin{tabular}{|c|c|c|c|c|c|}
\hline Common Name & Family (order) & Scientific name & \begin{tabular}{|l|} 
Survival commodity \\
\end{tabular} & Life span & References \\
\hline \multicolumn{6}{|c|}{ Cereals } \\
\hline $\begin{array}{l}\text { Lesser grain } \\
\text { borer }\end{array}$ & $\begin{array}{l}\text { Bostrichidae } \\
\text { (Coleoptera) }\end{array}$ & $\begin{array}{l}\text { Rhyzopertha dominica } \\
\text { (Fabricius) }\end{array}$ & $\begin{array}{c}\text { Infest all cereal grains, but } \\
\text { mostly occurs in wheat, corn, } \\
\text { rice and millet }\end{array}$ & 25 days at $34^{\circ} \mathrm{C}$. & Edde, $2012^{[16]}$ \\
\hline Granary weevil & $\begin{array}{c}\text { Curculionidae } \\
\text { (Coleoptera) }\end{array}$ & Sitophilus granarius $(\mathrm{L})$. & $\begin{array}{c}\text { wheat, corn, rye, oats, barley, } \\
\text { sorghum }\end{array}$ & \begin{tabular}{|c|}
$25-38$ days at $30{ }^{\circ} \mathrm{C}$ and \\
$70 \% \mathrm{RH}$
\end{tabular} & $\begin{array}{l}\text { Pražić-Golić et } \\
\text { al., 2011 [39] }\end{array}$ \\
\hline Rice weevil & $\begin{array}{c}\text { Curculionidae } \\
\text { (Coleoptera) }\end{array}$ & Sitophilus oryzae (L.) & $\begin{array}{c}\text { Rice, wheat, barley, } \\
\text { occasionally peas }\end{array}$ & $\begin{array}{c}25 \text { days at } 29.1^{\circ} \mathrm{C} \text { and } \\
70 \% \mathrm{RH} . \\
\end{array}$ & Batta, $2004^{[9]}$ \\
\hline Maize weevil & Curculionidae & $\begin{array}{l}\text { Sitophilus zeamais } \\
\text { Motschulsky }\end{array}$ & Maize, Grain, pasta & \begin{tabular}{|c|}
26 days at $30^{\circ} \mathrm{C}$ and 75 \\
to $76 \% \mathrm{RH}$. About 10 \\
generations in a year.
\end{tabular} & $\begin{array}{c}\text { Rees, } 2004^{40]} ; \\
\text { Kranz et al. }, 1997 \\
\text { [23] }\end{array}$ \\
\hline $\begin{array}{l}\text { Rusty grain } \\
\text { beetle }\end{array}$ & $\begin{array}{l}\text { Laemophloeidae } \\
\text { (Coleoptera) }\end{array}$ & $\begin{array}{c}\text { Cryptolestes } \\
\text { ferrugineus (Stephens) }\end{array}$ & $\begin{array}{l}\text { Wheat, barley, rye, triticale, } \\
\text { oats, and occasionally milled } \\
\text { products }\end{array}$ & Up to 9 months. & $\begin{array}{c}\text { Neethirajan } \text { et al., } \\
2007\end{array}$ \\
\hline Flour mill beetle & $\begin{array}{l}\text { Laemophloeidae } \\
\text { (Coleoptera) }\end{array}$ & $\begin{array}{c}\text { Cryptolestes } \\
\text { turcicus (Grouvelle) }\end{array}$ & $\begin{array}{l}\text { Flour, damaged grain } \\
\text { Waste grain }\end{array}$ & $\begin{array}{l}\text { Average life span is } 1 \\
\text { year, } 17-37^{\circ} \mathrm{C} \text { and } \\
\text { relative humidity } 90 \% \text {. }\end{array}$ & $\begin{array}{c}\text { Neethirajan et al., } \\
2007\end{array}$ \\
\hline $\begin{array}{l}\text { Merchant grain } \\
\text { beetle }\end{array}$ & Silvanidae (Coleoptera) & $\begin{array}{c}\text { Oryzaephilus mercator } \\
\text { (Fauvel) }\end{array}$ & $\begin{array}{c}\text { Prefers processed cereals, and } \\
\text { flours }\end{array}$ & $\begin{array}{c}\text { 14- } 46 \text { days at } 20^{\circ} \mathrm{C} \text {, and } \\
\text { at optimum condition of } \\
30-32 \cdot 5^{\circ} \mathrm{C} \text {. }\end{array}$ & Pierce et al., 1990 \\
\hline $\begin{array}{l}\text { Saw-toothed } \\
\text { grain beetle* }\end{array}$ & Silvanidae (Coleoptera) & $\begin{array}{c}\text { Oryzaephilus } \\
\text { surinamensis (L.) }\end{array}$ & $\begin{array}{l}\text { Oats, wheat, barley, animal } \\
\text { feed, flax, sunflower }\end{array}$ & \begin{tabular}{|c|}
$\begin{array}{c}3-4 \text { weeks at above } 30 \\
{ }^{\circ} \mathrm{C} \text {; longer life during } \\
\text { cooler months. }\end{array}$ \\
\end{tabular} & $\begin{array}{l}\text { Mowery et al., } \\
2002\end{array}$ \\
\hline $\begin{array}{l}\text { Long headed } \\
\text { flour beetle }\end{array}$ & $\begin{array}{l}\text { Tenebrionidae } \\
\text { (Coleoptera) }\end{array}$ & $\begin{array}{c}\text { Latheticus } \\
\text { oryzae Waterhouse }\end{array}$ & Sorghum, maize & $\begin{array}{c}\text { Adults live for up to } 112 \\
\text { days, requires } 25^{\circ} \mathrm{C} \\
\text { requires for development } \\
\text { to occur. }\end{array}$ & Atwa, 1986 \\
\hline $\begin{array}{l}\text { Red flour } \\
\text { beetle** }\end{array}$ & $\begin{array}{c}\text { Tenebrionidae } \\
\text { (Coleoptera) }\end{array}$ & $\begin{array}{c}\text { Tribolium } \\
\text { castaneum (Herbst) }\end{array}$ & \begin{tabular}{|c|} 
Stored grains, oilseeds \\
Starchy materials, beans, peas
\end{tabular} & $\begin{array}{r}30 \text { days in s } \\
\text { longer life }\end{array}$ & $\begin{array}{c}\text { Neethirajan } \text { et al., } \\
2007\end{array}$ \\
\hline $\begin{array}{l}\text { Confused flour } \\
\text { beetle** }\end{array}$ & $\begin{array}{l}\text { Tenebrionidae } \\
\text { (Coleoptera) }\end{array}$ & Tribolium confusum & $\begin{array}{c}\text { Grains, cereal products, flour, } \\
\text { animal feed, sunflower, millet } \\
\text { Starchy materials, beans, peas, } \\
\text { spices }\end{array}$ & 42 days at above $30^{\circ} \mathrm{C}$ & $\begin{array}{c}\text { Baldwin and } \\
\text { Fasulo, 2003 }\end{array}$ \\
\hline $\begin{array}{l}\text { Large flour } \\
\text { beetle }\end{array}$ & $\begin{array}{l}\text { Tenebrionidae } \\
\text { (Coleoptera) }\end{array}$ & $\begin{array}{c}\text { Tribolium } \\
\text { destructor Uyttenboogaart }\end{array}$ & $\begin{array}{l}\text { Seeds, cereals, flour, stored } \\
\text { grain, bran }\end{array}$ & $\begin{array}{l}\text { Adults survive up to } 1 \\
\text { year, Survive below } 30 \\
{ }^{\circ} \mathrm{C} \text {. }\end{array}$ & $\begin{array}{c}\text { Schreurs and } \\
\text { Janovy, 2008 }\end{array}$ \\
\hline $\begin{array}{l}\text { Angoumois } \\
\text { grain moth }\end{array}$ & $\begin{array}{c}\text { Gelichiidae } \\
\text { (Lepidoptera) }\end{array}$ & $\begin{array}{l}\text { Sitotroga cerealella } \\
\text { (Olivier) }\end{array}$ & $\begin{array}{l}\text { Wheat, barley, corn, rice, } \\
\text { sorghum, millet }\end{array}$ & $\begin{array}{c}35 \text { days at } 30^{\circ} \mathrm{C} \text { and } 75- \\
76 \% \mathrm{RH} \text {. }\end{array}$ & $\underset{[43]}{\text { Saikia } \text { et al., } 2014}$ \\
\hline $\begin{array}{l}\text { Indian meal } \\
\text { moth }\end{array}$ & $\begin{array}{c}\text { Pyralidae } \\
\text { (Lepidoptera) }\end{array}$ & Plodia interpunctella & $\begin{array}{l}\text { Most common moth pest of } \\
\text { stored grains. }\end{array}$ & $\begin{array}{c}28-35 \text { days at optimum } \\
\text { condition of } 30-35{ }^{\circ} \mathrm{C} \\
\text { and } 25 \% \text { relative } \\
\text { humidity. }\end{array}$ & $\begin{array}{c}\text { Mewis and } \\
\text { Ulrichs, } 2001^{[29]}\end{array}$ \\
\hline $\begin{array}{l}\text { Yellow } \\
\text { mealworm }\end{array}$ & $\begin{array}{l}\text { Tenebrionidae } \\
\text { (Coleoptera) }\end{array}$ & Tenebrio molitor $\mathrm{L}$. & $\begin{array}{l}\text { Prefers decaying grain or } \\
\text { milled cereals }\end{array}$ & $\begin{array}{l}\text { Larvae survive up to } 21 \\
\text { days at } 15^{\circ} \mathrm{C} \text {. }\end{array}$ & $\begin{array}{c}\text { Sadd } \text { et al., } 2006 \\
\text { [42]; Upadhyay } \\
\text { and Ahmad, } 2011 \\
{[54]}\end{array}$ \\
\hline \multicolumn{6}{|c|}{ Pulses } \\
\hline Bean Weevil & $\begin{array}{l}\text { Chrysomelidae } \\
\text { (Coleoptera) }\end{array}$ & Acanthoscelides obtectus & $\begin{array}{c}\text { Beans, lentil, chickpea, } \\
\text { soybean }\end{array}$ & $\begin{array}{l}\text { 21-28 days at the } \\
\text { temperature above } 30\end{array}$ & $\begin{array}{c}\text { Regnault-Roger } e t \\
\text { al., } 1995^{[41]}\end{array}$ \\
\hline
\end{tabular}




\begin{tabular}{|c|c|c|c|c|c|}
\hline & & & & $\begin{array}{c}{ }^{\circ} \mathrm{C} \text {; more proliferation in } \\
\text { cooler months. 5-6 } \\
\text { generations in a year. }\end{array}$ & \\
\hline Pea Weevil & $\begin{array}{c}\text { Chrysomelidae } \\
\text { (Coleoptera) }\end{array}$ & Bruchus pisorum (Linnaeus) & Peas & $\begin{array}{c}21 \text { days at } 30{ }^{\circ} \mathrm{C} \text { and } \\
70 \% \mathrm{RH}\end{array}$ & Sarwar, $2015^{[42]}$ \\
\hline Cowpea beetle & $\begin{array}{l}\text { Chrysomelidae } \\
\text { (Coleoptera) }\end{array}$ & Callosobruchus maculatus & $\begin{array}{l}\text { Cowpea, beans, peas, green } \\
\text { gram }\end{array}$ & $\begin{array}{c}\text { 10-14 days. More } \\
\text { proliferation in cooler } \\
\text { months. }\end{array}$ & $\begin{array}{l}\text { Tiroesele, } 2014 \\
{[53] ; \text { Devi et al., }} \\
2014^{[15]}\end{array}$ \\
\hline Pulse beetle & $\begin{array}{l}\text { Chrysomelidae } \\
\text { (Coleoptera) }\end{array}$ & $\begin{array}{l}\text { Callosobruchus } \\
\text { chinensis (L.) }\end{array}$ & $\begin{array}{l}\text { Green gram, lentil, chickpea, } \\
\text { cowpea and pigeon pea }\end{array}$ & $\begin{array}{c}21 \text { days at } 30^{\circ} \mathrm{C} \text { and } \\
70 \% \mathrm{RH} .\end{array}$ & $\begin{array}{c}\text { Patel } \text { et al., } 2005 \\
\text { [36]; Pokharkar } \\
\text { and Mehta, } 2011 \\
\text { [38] }\end{array}$ \\
\hline \multicolumn{6}{|c|}{ Cereals and Pulses } \\
\hline Flat grain beetle & $\begin{array}{l}\text { Laemophloeidae } \\
\text { (Coleoptera) }\end{array}$ & $\begin{array}{c}\text { Cryptolestes } \\
\text { pusillus (Schönherr) }\end{array}$ & Cereals and pulses & $\begin{array}{c}4-5 \text { weeks and adults } \\
\text { may survive up to one } \\
\text { year. Larvae developed } \\
\text { at a higher rate at } 90 \% \\
\text { than at } 70 \% \text { relative } \\
\text { humidity. }\end{array}$ & $\begin{array}{c}\text { Millar et al., } 1985 \\
{[30]}\end{array}$ \\
\hline \multicolumn{6}{|c|}{ Oilseeds } \\
\hline Khapra beetle & $\begin{array}{l}\text { Dermestidae } \\
\text { (Coleoptera) }\end{array}$ & $\begin{array}{c}\text { Trogoderma } \\
\text { granarium Everts }\end{array}$ & Grains and oilseeds & $\begin{array}{l}\text { 14-30 days in high } \\
\text { humidity regions. }\end{array}$ & $\begin{array}{l}\text { Ahmedani } \text { et al., } \\
2007^{[2]}\end{array}$ \\
\hline
\end{tabular}

*Survive in both cereals and oilseeds

** Survive in cereals, oilseeds, and pulses

\subsection{Infestation in Cereals}

In developing countries viz. India, about 50-60\% of food grains are stored in traditional storage structures and at farm level (Anonymous, 2014; Kumar and Kalita, 2017) ${ }^{[3,24]}$ and about $30-40 \%$ losses are occurred in the grains due to insect infestation (Boxall, 2002; Abass et al., 2014) ${ }^{[1]}$. Losses incurred from insect infestation are boundless and commits quality loss, quantity loss, and grade (Harein and Meronuck, 1995). Rhizopertha dominica F. and Trogoderma granarium are the two most calamitous insects for stored cereal grains. In 1980, Boxall, (2002) reported the 50\% losses in stored maize due to insect infestation. Pantenius (1988) found that about $80-90 \%$ losses during storage of maize occurred due to insect infestation. Jha et al. (2015) found that total storage losses including godowns, wholesale retailers, and processing unit acquired $0.86,0.86,0.75,0.79$, and $1.21 \%$ in wheat, paddy, maize, millet, and sorghum, respectively. Khaliq et al. (2014) determined the nutritional losses in rice genotypes at $28{ }^{\circ} \mathrm{C}$, $32{ }^{\circ} \mathrm{C}$ and $35^{\circ} \mathrm{C}$ against Tribolum castaneum (Herbst). They found that insects caused reasonable losses in nutritional characteristics. Effect of storage and Sitophilus granarius on the technological properties of wheat was studied and found that kernel and fat content decreased, and due to this bread properties deteriorated (Keskin and Ozkaya, 2015). Larger grain borers (Prostephanus truncatus) and maize weevil (Sitophilus zeamais) major stored pest of maize, caused $23 \%$ losses during 6 months storage and 56.7\% losses after 6 months storage (Kumar and Kalita, 2017, Abass et al., 2014 and Kimenju et al., 2010) ${ }^{[24,1]}$. Lesser grain borer is the most dangerous insect, caused about 30\% weight loss in stored maize (Boxall, 2002) ${ }^{[13]}$. Patel et al. (1993) ${ }^{[35]}$ found that $R$. dominica caused $25 \%$ losses in stored wheat. Storage losses can be reduced by using the appropriate storage structures such as infestation level of $C$. maculatus on the seeds during the four months storage was reduced in Super grain bags as compared to the PICS (Purdue Improved Crop Storage) bag (Baoua et al., 2014) ${ }^{[10]}$. Somavat et al. (2014) reported the compared results of hermetic bin bags, metallic bins and gunny bags and found that there was no infestation in hermetic bags after nine months of wheat storage and seed viability was higher $(88 \%)$ in hermetically stored grains (Somavat et al., 2015 and Kumar et al., 2017) ${ }^{[50,24]}$.

\subsection{Infestation in Food Legumes}

During storage of food legumes in storage or on farm structures prior to processing, many physiological changes occurs which causes the reduction in quantitative as well as qualitative and therefore economic losses (Banga et al., 2019) [8]. Mookherjee et al. (1970) [32] and Gangrade (1974) [18] found that infestation in pulses occurred due to bruchids, which causes the major losses in pulses during storage. Bruchids eat the whole kernel and left only the pericarp, which makes the seed inedible and unfeasible. In pulses, about $90 \%$ of infestation are arises due to Callosobruchus chinesis, Callosobruchus maculatus and Callosobruchus analis in India (Sivakumar, 2010) ${ }^{[48]}$. Among these species of genus Callosotbruchus, C. maculatus and $C$. chinensis are one of the most calamitous insect during storage of cowpea, chickpea, mung, garden pea, black gram, lentil, and pigeon pea (Iturralde-García et al., 2016; Banga et al., 2018) ${ }^{[7,21]}$. These insect assails wild and cultivated legumes, specifically Vigna radiata (Messina and Mitchell, 1989) ${ }^{[28]}$. Losses incurring in stored pulses by $C$. chinensis infestation has been reported from Philippines, Japan, Indonesia, Sri Lanka, Burma, India and Bangladesh (Mahdi and Rahman, 2008) ${ }^{[27]}$. Gujar and Yadav, (1978) reported that about 55$69 \%$ seed weight loss and 45.6-66.3\% loss in protein content of chickpea by the pulse beetle. In Nigeria, about $24 \%$ losses in stored pulses occurred due to C. maculatus (Tapondjou et al., 2002). In tropical regions insect leads to $100 \%$ detrimental effects in stored pulses (Egwuatu, 1987) [17]. Birewar, (1984) ${ }^{[12]}$ reported about $9.5 \%$ of post-harvest losses in pulses, in which about $7.5 \%$ losses occurred due to storage alone. In chickpea and lentil, about $30 \%$ and $15 \%$ storage losses found in India, respectively. About 10-15\% losses along with $50-92 \%$ germination losses are caused by bruchids in stored cereals and pulses (Haile, 2006) ${ }^{[20]}$. Mutungi et al. (2014) ${ }^{[34]}$ determined the efficacy of the PICS bags under natural infestation and artificial infestation in green gram and pigeonpeas and found the average change in infestation level of both the condition of PICS stored legumes. Singh et al. (2012) ${ }^{[27]}$ evaluated the mortality of $C$. chinensis, treated by microwave radiation and found that seed viability and germination of chickpea, pigeon pea, and green gram decreased with microwave radiation exposed time and power 
level. Mohapatra et al. (2014) [31] reported the effect of microwave heating on adult $C$. maculatus for different grain bed thickness and concluded that microwave heating had no significant effect on moisture loss, cooking time and protein content.

\subsection{Infestation in oilseeds}

A large variety of pests damage oilseeds and cause significant losses in the farms or during storages. Insects cause significant economic losses in oilseeds. Classification of oilseed insect pest depends on taxonomic grouping, distribution and feeding habitat. Insect infestation of sunflower kernels during storage affected the kernel and reduced the oil content due to increase in moisture content and temperature. Soybean can be safely stored at maximum safe drying temperatures are $43{ }^{\circ} \mathrm{C}$ for soybeans intended for seeding purposes and $49{ }^{\circ} \mathrm{C}$ for commercial use.

\section{Conclusion}

Insects infestation in stored grains causes a huge loss by contaminating it or by eating it. Therefore it is necessary to understand the behavior, type of insects and their life cycle to reduce the post-harvest losses. Knowledge of insects would also help in monitoring and assessment of their damage in stored food grains by adopting the suitable technology. It should be necessary to grain storage handlers to know about the insects morphology and apply the appropriate technology to reduce the losses caused by them. It is need of time to reduce the post-harvest losses of food grains to fulfill the requirement of increasing population.

\section{References}

1. Abass AB, Ndunguru G, Mamiro P, Alenkhe B, Mlingi $\mathrm{N}$, Bekunda M. Post-harvest food losses in a maize-based farming system of semi-arid savannah area of Tanzania. Boxall, R. A. Damage and loss caused by the larger grain borer Prostephanus truncatus. Journal of Stored Products Research. 2014; 57:49-57.

2. Ahmedani MS, Abdulkhalig MT, Tarig M, Anwar M, Naz S. Khapra beetle (Trogoderma granarium Everts): A serious threat to food security and safety. Pak. J. Agri. Sci, 2007; 44(3):481-493.

3. Anonymous. Food and Agriculture Organization of United Nations. Global Initiative on Food Losses and Waste Reduction; FAO: Rome, Italy. 2014.

4. Anonymous. Indian Grain Storage Management and Research Institute, Hapur, Ministry of Consumer Affairs, Food and Public Distribution, Department of Food and Public Distribution, Government of India. 2015.

5. Atwa WAA. Biological studies on Latheticusoryzae Waterhouse (Coleoptera: Tenebrionidae). Monoufeya Journal of Agricultural Research (Egypt). 1986.

6. Baldwin R, Fasulo TR. Confused Flour Beetle, Tribolium confusum Jacquelin du Val (Insecta: Coleoptera: Tenebrionidae) and Red Flour Beetle, Tribolium castaneum (Herbst) (Insecta: Coleoptera: Tenebrionidae). USA: University of Florida IFAS Extension. 2003.

7. Banga KS, Kotwaliwale N, Mohapatra D, Giri SK. Techniques for insect detection in stored food grains: An overview. Food Control. 2018; 94:167-176.

8. Banga KS, Kotwaliwale N, Mohapatra D, Giri SK, Babu VB. Bioacoustic detection of Callosobruchus chinensis and Callosobruchus maculatus in bulk stored chickpea
(Cicer arietinum) and green gram (Vigna radiata). Food Control, 2019; 104:278-287.

9. Batta YA. Control of rice weevil (Sitophilus oryzae L., Coleoptera: Curculionidae) with various formulations of Metarhizium anisopliae. Crop Protection. 2004; 23(2):103-108.

10. Baoua IB, Amadou L, Baributsa D, Murdock LL. Triple bag hermetic technology for post-harvest preservation of Bambara groundnut (Vigna subterranea (L.) Verdc.). Journal of Stored Products Research. 2014; 58:48-52.

11. Bell $\mathrm{CH}$. A review of insect responses to variations encountered in the managed storage environment. Journal of Stored Products Research. 2014; 59:260-274.

12. Birewar, B.R. Post-Harvest Technology of Pulses, Pulse Production - Constraints and Opportunities. Oxford and IBH Publishing Co., New Delhi, India. 1984, 425-438.

13. Boxall RA. Damage and loss caused by the larger grain borer Prostephanus truncatus. Integrated Pest Management Reviews, 2002; 7(2):105-121.

14. Chakravarty A. Post-Harvest Technology of Cereals, Pulses and oilseeds, third edition, Oxford \& IBH Publishing Co. Pvt. Ltd. 2014.

15. Devi MB, Devi NV. Biology and morphometric measurement of cowpea weevil, Callosobruchus maculatus Coleoptera: Chrysomelidae) in green gram. Journal of Entomology and Zoology Studies, 2014, 2(3):74-76.

16. Edde, Peter A. A review of the biology and control of Rhyzopertha dominica (F.) the lesser grain borer. Journal of Stored Products Research. 2012; 48:1-18.

17. Egwuatu RI. Current status of conventional insecticides in the management of stored product insect pests in the tropics. International Journal of Tropical Insect Science. 1987; 8(4-5-6):695-701.

18. Gangrade GA. Insects of soybean. Technical Bulletin Jawaharlal Neru Krishi Vishwa Vidyalaya, 1974; 24:88.

19. Gujar GT, Yadav TD. Feeding of Callosobruchus maculatuts (Fab.) and Callosobruchus chinensis (Linn.) in green gram. Indian journal of entomology. 1978.

20. Haile, A. On-farm storage studies on sorghum and chickpea in Eritrea. African Journal of Biotechnology. 2006, 5(17).

21. Iturralde-García RD, Borboa-Flores J, Cinco-Moroyoqui FJ, Riudavets J, Del Toro-Sánchez CL, Rueda-Puente, Effect of controlled atmospheres on the insect Callosobruchus maculatus Fab. in stored chickpea. Journal of Stored Products Research, 2016; 69, 78-85.

22. Kimenju SC, De Groote H. Economic analysis of alternative maize storage technologies in Kenya. In Joint 3rd African Association of Agricultural Economists (AAAE) and 48th Agricultural Economists Association of South Africa (AEASA) Conference, Cape Town, South Africa, 2010, 19-23.

23. Kranz JK, Schmutterer H, Koch W. Diseases, pests and weeds in tropical crops. New York: Wesly, 1997, 666.

24. Kumar D, Kalita P. Reducing Postharvest Losses during Storage of Grain Crops to Strengthen Food Security in Developing Countries. Foods, 2017; 6(1):8.

25. Kumar G, Rai DV. Management strategies for storage, disinfestation and insect detection of grains and seeds. Progressive Agriculture. 2014; 14(1):87-101.

26. Kumar S, Mohapatra D, Kotwaliwale N, Singh KK, Vacuum Hermetic Fumigation: A review. Journal of Stored Products Research, 2017; 71:47-56. 
27. Mahdi SHA, Rahman MK. Insecticidal effect of some spices on Callosobruchus maculatus (Fabricius) in black gram seeds. University journal of zoology, Rajshahi University, 2008; 27:47-50.

28. Messina FJ, Mitchell, R. Intraspecific variation in the egg-spacing behavior of the seed beetle Callosobruchus maculatus. Journal of Insect Behavior, 1989; 2(6):727742.

29. Mewis I, Ulrichs C. Action of amorphous diatomaceous earth against different stages of the stored product pests Tribolium confusum, Tenebrio molitor, Sitophilus granarius and Plodia interpunctella. Journal of Stored Products Research, 2001; 37(2):153-164.

30. Millar JG, Pierce HD, Pierce AM, Oehlschlager AC, Borden JH, Barak AV. Aggregation pheromones of the flat grain beetle, Cryptolestes pusillus (Coleoptera: Cucujidae). Journal of chemical ecology, 1985; 11(8):1053-1070.

31. Mohapatra D, Giri SK, Kar A. Effect of microwave aided disinfestation of Callosobruchus maculatus on green gram quality. International Journal of Agriculture and Food Science Technology, 2014; 5(2):55-62.

32. Mookherjee PB, Jotwani MG, Yadav TD, Sricar P. Studies on incidence and extent of damage due to insect pest in stored seeds II leguminous and vegetable seeds. Indian Journal of Entomolgy, 1970; 32:350-355.

33. Mowery SV, Mullen MA, Campbell JF, Broce AB. Mechanisms underlying saw-toothed grain beetle (Oryzae philussurinamensis [L.]) (Coleoptera: Silvanidae) infestation of consumer food packaging materials. Journal of Economic Entomology, 2002; 95(6):13331336.

34. Mutungi CM, Affognon H, Njoroge AW, Baributsa D, Murdock LL. Storage of mung bean (Vigna radiata [L.] Wilczek) and pigeonpea grains (Cajanus cajan [L.] Millsp) in hermetic triple-layer bags stops losses caused by Callosobruchus maculatus (F.) (Coleoptera: Bruchidae). Journal of Stored Products Research, 2014; 58:39-47.

35. Patel KP, Valand VM, Patel SN. Powder of neem-seed kernel for control of lesser grainborer (Rhizopertha dominica) in wheat (Triticum aestivum). Indian Journal of Agricultural Sciences (India). 1993.

36. Patel VK, Chaudhuri N, Senapati SK. Biology of pulse beetle (Callosobruchus chinensis Linn.) as influenced by feeding of different grain pulses. Agricultural Science Digest, 2005; 25(4):254-256.

37. Pierce AM, Pierce HD, Oehlschlager AC, Borden JH. Attraction of Oryzaephilus surinamensis (L.) and Oryzaephilus mercator (Fauvel) (Coleoptera: Cucujidae) to some common volatiles of food. Journal of chemical ecology, 1990; 16(2):465-475.

38. Pokharkar PK, Mehta DM. Biology of pulse beetle, Callosobruchus chinensis in stored chickpea. Progressive Agriculture, 2011; 11(1):34-36.

39. Pražić-Golić M, Andrić G, Kljajić P. Effects of $50 \mathrm{C}$ temperature on Sitophilus granarius (L.), Sitophilus oryzae (L.) and Sitophilus zeamais (Motsch.). Pesticidi fitomedicina, 2011; 26(3):221-227.

40. Rees DP. Insects of stored products. Manson Publishing Ltd. London, 2004.

41. Regnault-Roger C, Hamraoui A. Fumigant toxic activity and reproductive inhibition induced by monoterpenes on Acanthoscelides obtectus (Say) (Coleoptera), a bruchid of kidney bean (Phaseolus vulgaris L.). Journal of Stored Products Research. 1995; 31(4):291-299.

42. Sadd B, Holman L, Armitage H, Lock F, Marland R, Siva- Jothy MT. Modulation of sexual signalling by immune challenged male mealworm beetles (Tenebrio molitor, L.): evidence for terminal investment and dishonesty. Journal of evolutionary biology, 2006, 19(2):321-325.

43. Saikia J, Goswami MM, Bhattacharyya B. Biology and detection technique of Angoumois grain moth, Sitotroga cerealella Olivier (Lepidoptera: Gelechiidae) on stored rice and maize grains. J. Entomol. Zool. Stud, 2014, 2:911.

44. Sallam MN. Insect damage: damage on postharvest. AGSI/FAO: INPhO. 2008. Available via http://www. fao. org/inpho/content/compend/text/ch0201. htm. Accessed, 22.

45. Sarwar M. Distinguishing and controlling insect pests of stored foods for improving quality and safety. American Journal of Marketing Research. 2015; 1(3):201-207.

46. Schreurs J, Janovy Jr, J. Gregarines on a diet: The effects of host starvation on Gregarina confuse (Apicomplexa: Eugregarinida) in Tribolium destructor Uyttenboogaart, (Coleoptera: Tenebrionidae) larvae. Journal of Parasitology. 1933, 2008, 94(3):567-570.

47. Singh R, Singh KK, Kotwaliwale N. Study on disinfestation of pulses using microwave technique. Journal of food science and technology. 2012; 49(4):505509.

48. Sivakumar C, Chandrasekaran S, Vijayaraghavan C, Selvaraj S. Fumigant toxicity of essential oils against pulse beetle, Callosobruchus maculates (F.) (Coleoptera: Bruchidae), J Biopesticides, 2010; 3(1):317-319.

49. Somava P, Huang H, Kumar S, Garg MK, Danao MGC, Singh V et al. Comparison of Hermetic Storage of Wheat with Traditional Storage Methods in India. In 2014 Montreal, Quebec Canada July 13-July 16, 2014 (p. 1). American Society of Agricultural and Biological Engineers. 2014.

50. Somavat P, Huang H, Kumar S, Garg M, Danao M, Singh V et al. Hermetic wheat storage for small holder farmers in India. In Proceedings of the First International Congress on Postharvest Loss Prevention, Rome, Italy. 2015.

51. Srivastava C, Subramanian S. Storage insect pests and their damage symptoms: an overview. Indian Journal of Entomology. 2016; 78(special):53-58.

52. Tapondjou LA, Adler CLAC, Bouda H, Fontem DA. Efficacy of powder and essential oil from Chenopodium ambrosioides leaves as post-harvest grain protectants against six-stored product beetles. Journal of stored products Research. 2002; 38(4):395-402.

53. Tiroesele B, Thomas K, Seketeme S. Control of cowpea weevil, Callosobruchus maculatus (F.) (Coleoptera: Bruchidae), using natural plant products. Insects, 2014; 6(1):77-84.

54. Upadhyay RK, Ahmad S. Management strategies for control of stored grain insect pests in farmer stores and public ware houses. World J Agric Sci. 2011; 7:527-549. 